\title{
The 2002/2003 radionuclide concentration in the marine environment at various distances from the Barsebäck nuclear power plant
}

\author{
M. ZAKARIA ${ }^{1, *}$, C.L. RÄ̈̈F ${ }^{1}$, S. MATTSSON ${ }^{1}$
}

(Manuscript received 4 February 2008, accepted 25 March 2008)

ABSTRACT The activity concentration of ${ }^{137} \mathrm{Cs},{ }^{131} \mathrm{I},{ }^{65} \mathrm{Zn},{ }^{60} \mathrm{Co},{ }^{58} \mathrm{Co},{ }^{54} \mathrm{Mn}$, and ${ }^{40} \mathrm{~K}$ were determined in samples of brown seaweed (Fucus) and some other marine plants using low background high-resolution gamma-spectrometry. The algae were mainly sampled in the bay just north of the Barsebäck NPP $(55.4 \mathrm{~N}, 12.6 \mathrm{E})$ in the south of Sweden to study the contamination levels in the nearest shallow waters. One aim of the study was to investigate whether the levels were high enough to expect environmental effects. Some samples were also taken at longer distances up to $130 \mathrm{~km}$ from the Barsebäck NPP. Measurable levels of the neutron activation products ${ }^{65} \mathrm{Zn}$ (up to $17 \mathrm{~Bq} / \mathrm{kg} \mathrm{dw}$ ), ${ }^{60} \mathrm{Co}(100-600 \mathrm{~Bq} / \mathrm{kg} \mathrm{dw}),{ }^{58} \mathrm{Co}(1-160 \mathrm{~Bq} / \mathrm{kg} \mathrm{dw})$ and ${ }^{54} \mathrm{Mn}(12-90 \mathrm{~Bq} / \mathrm{kg} \mathrm{dw})$ were found in the algae samples within a distance of $5 \mathrm{~km}$ from the plant. The decrease in activity concentration with distance from the plant could be described by a power function with an exponent ranging from 1.4 to 2.4. This was in fair agreement with the value for a true two-dimensional dispersion model. The present-day concentrations were found to be considerably lower than in earlier studies made in the late 1970 s, especially for ${ }^{65} \mathrm{Zn}$ and ${ }^{58} \mathrm{Co}$. The activity concentration of gamma emitting radionuclides in Fucus vesiculosus from the bay just north of Barsebäck in the period 2002-2003 was dominated by (in order of decreasing concentration): natural ${ }^{40} \mathrm{~K},{ }^{60} \mathrm{Co}$ from the plant, ${ }^{137} \mathrm{Cs}$ mainly from the Chernobyl debris, ${ }^{54} \mathrm{Mn}$ and ${ }^{58} \mathrm{Co}$ from the plant. It is not likely that any effects from the very marginal absorbed dose contribution from the Barsebäck NPP releases can be found even in the nearest environment. The study has also shown that the eelgrass Zostera marina may be a bioindicator to use in further studies of the radiation environment in shallow water, especially for ${ }^{60} \mathrm{Co}$ and ${ }^{54} \mathrm{Mn}$.

Keywords: Barsebäck NPP / fucus / activation products / marine environment

RÉSUMÉ La concentration de radionucléides - en 2002/2003 - dans l'environnement marin, à diverses distances de la centrale électronucléaire de Barsebäck.

On a utilisé la spectrométrie gamma de haute résolution et à bas bruit de fond, pour déterminer les concentrations de l'activité de ${ }^{137} \mathrm{Cs},{ }^{131} \mathrm{I},{ }^{65} \mathrm{Zn},{ }^{60} \mathrm{Co},{ }^{58} \mathrm{Co},{ }^{54} \mathrm{Mn}$ et ${ }^{40} \mathrm{~K}$ dans des échantillons de goémon brun (Fucus) et de plusieurs autres plantes marines. On prélevait les algues surtout dans la baie située juste au nord de la centrale électronucléaire de Barsebäck $(55,4 \mathrm{~N}, 12,6 \mathrm{E})$, au sud de la Suède, pour étudier les niveaux de contamination des hauts fonds les plus proches. On a aussi

${ }^{1}$ Department of Radiation Physics, Lund University, Malmö University Hospital, 20502 Malmö, Sweden.

* Corresponding author: zakaria.mohamad@gmail.com 


\begin{abstract}
collecté quelques échantillons à des distances plus grandes, allant jusqu'à 130 km de la centrale électronucléaire de Barsebäck. Pour des distances à la centrale inférieures à $5 \mathrm{~km}$, on a trouvé, dans les échantillons d'algues, des niveaux mesurables de produits d'activation neutronique, ${ }^{65} \mathrm{Zn}$ (jusqu'à $17 \mathrm{~Bq} / \mathrm{kg} \mathrm{dw}$ ), ${ }^{60} \mathrm{Co}$ $(100-600 \mathrm{~Bq} / \mathrm{kg} \mathrm{dw}),{ }^{58} \mathrm{Co}(1-160 \mathrm{~Bq} / \mathrm{kg} \mathrm{dw})$ et ${ }^{54} \mathrm{Mn}(12-90 \mathrm{~Bq} / \mathrm{kg} \mathrm{dw})$. La décroissance de la concentration de l'activité en fonction de la distance $x$ à la centrale, peut se représenter par une fonction $\alpha x^{-\beta}, \beta$ étant compris entre 1,4 et 2,4. Ce résultat est en honnête accord avec la valeur déduite d'un modèle valable de dispersion à deux dimensions. Les concentrations actuelles sont considérablement plus faibles que celles obtenues dans des études antérieures, effectuées à la fin des années 70, particulièrement en ce qui concerne ${ }^{65} \mathrm{Zn}$ et ${ }^{58} \mathrm{Co}$. Dans la période 20022003, la concentration de l'activité de radionucléides émetteurs gamma dans le goémon (Fucus vesiculosus) venant de la baie au nord de Barsebäck était dominée (dans l'ordre des concentrations décroissantes) par ${ }^{40} \mathrm{~K}$ naturel, ${ }^{60} \mathrm{Co}$ venant de la centrale, ${ }^{137} \mathrm{Cs}$ venant principalement des retombées de Chernobyl, ${ }^{54} \mathrm{Mn}$ et ${ }^{58} \mathrm{Co}$ venant de la centrale. Il n'est pas probable que l'on puisse trouver, même dans l'environnement le plus proche, quelque effet que ce soit venant de la contribution très marginale à la dose absorbée des rejets de la centrale électronucléaire de Barsebäck. Cette étude a également montré que la zostère Zostera marina peut s'avérer un bioindicateur à employer dans les études ultérieures de l'environnement radioactif sur les hauts fonds, en particulier en ce qui concerne ${ }^{60} \mathrm{Co}$ et ${ }^{54} \mathrm{Mn}$.
\end{abstract}

\title{
1. Introduction
}

During normal operation of a nuclear power plant (NPP), small controlled releases mainly of neutron activation products are common and occur through the cooling water outlet. Until November 1999, the Barsebäck nuclear power plant (Barsebäck NPP) consisted of two reactors in operation, Barsebäck-1 (between 1976 and 1999) and Barsebäck-2 (since 1977), both of boiling water type, having an electrical power of $600 \mathrm{MW}$, or $1700 \mathrm{MW}$ thermal power each. Barsebäck-2 has been shut down since the year 2005 .

The radiation environment in the vicinity of the plant is relatively well known due to a long-term monitoring programme of the radionuclide concentration in a number of species, both terrestrial and aquatic (Wijk and Luning, 2001). There have also been several research programmes since the start of the operation of the reactors (Mattsson et al., 1980a). Among the most frequently found radionuclides in the vicinity of the NPP are ${ }^{65} \mathrm{Zn},{ }^{60} \mathrm{Co},{ }^{58} \mathrm{Co}$, and ${ }^{54} \mathrm{Mn}$. There is normally also ${ }^{137} \mathrm{Cs}$, which originates from various sources. Environmental contamination by ${ }^{137} \mathrm{Cs}$ is of particular public health interest because of the various sources of fallout originating from nuclear weapons, radiological source disruptions, and the Chernobyl disaster. This dispersion may lead to a chronic ecosystem contamination and subsequent ingestion of contaminated foodstuffs.

This study investigates how the various radionuclides are distributed in the vicinity of the plant. Even though the discharged radionuclides from the Barsebäck NPP are dispersed into large volumes of water, one of the bio-indicator used here, 
the brown seaweed (Fucus), has the ability to accumulate several of the radionuclides of interest into its biomass in measurable quantities (Mattsson et al., 1980a; Nilsson et al., 1980). The results are compared with those of a similar research performed in 1977 and from other studies in the area (Mattsson et al., 1980b; Holm, 1994).

Another aim of the study is to investigate whether the activity concentration in some of the organisms that are commonly found in the Öresund is high enough to give any radiation effects.

\section{Material and methods}

Samples of Fucus vesiculosus were collected along the Swedish shore of the Öresund and Kattegat at different distances from the Barsebäck NPP (Fig. 1). The samples were collected between March 2002 and March 2003. The depth of water at the sampling sites varied between 0.5 and $1 \mathrm{~m}$. All the seaweed samples (whole

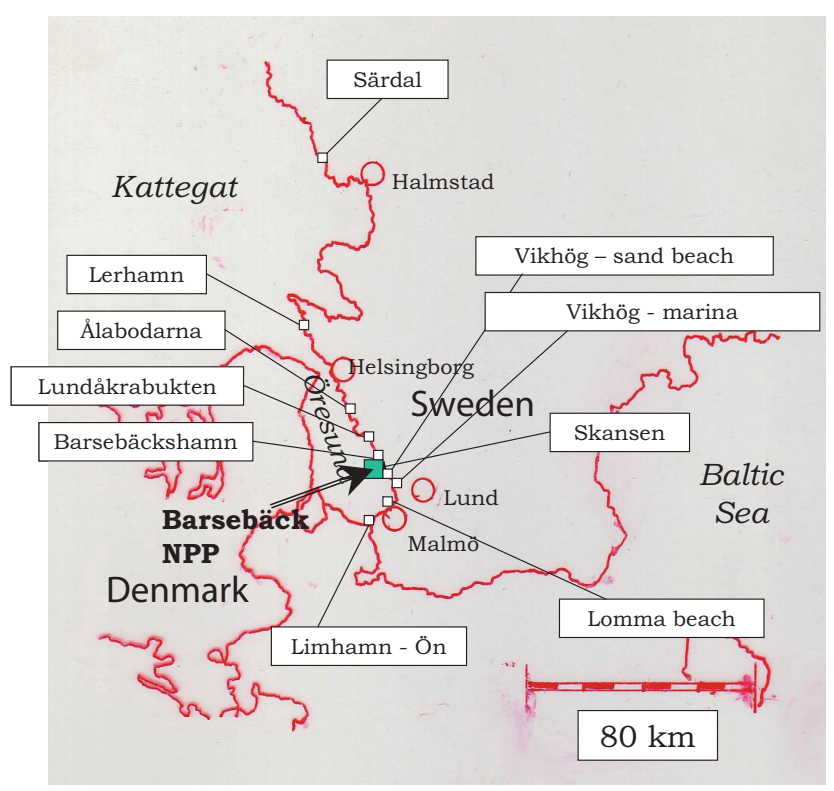

Figure 1 - Sampling points of Fucus vesiculosus (and in some cases additional sampling of Fucus serratus, Entermorpha intestinalis, Zostera marina, Mytilus edulis) in the Swedish coast of the Öresund and Kattegat.

Points de prélèvement de Fucus vesiculosus (avec, dans certains cas, des échantillons additionnels de Fucus serratus, Entermorpha intestinalis, Zostera marina, Mytilus edulis) sur la côte suédoise de l'Öresund et du Kattegat. 
Fucus plant) collected were firmly rooted to the bottom of the waters, most often on stones. At collection, the samples were put into plastic bags. All the samples were dried at room temperature $\left(\sim 20^{\circ} \mathrm{C}\right)$ for a period of five days. Afterwards, the samples were grounded using a laboratory mill. Furthermore, the grounded samples were put in $150 \mathrm{ml}$ pre-weighed plastic beakers and the net weight was recorded.

From one sampling spot (Lundåkrabukten), around $6 \mathrm{~km}$ north of the Barsebäck NPP, samples of Fucus vesiculosus, eelgrass (Zostera marina), light green algae (Entermorpha intestinalis), mussels (Mytilus edulis) clean from any micro algae, as well as mussels with micro algae on their surface were sampled on August 2nd, 2002. The eelgrass, light green algae, as well as mussel samples were dried at $110^{\circ} \mathrm{C}$ for 24 hours while the Fucus vesiculosus was dried at room temperature for 5 days.

After the sample preparation was completed, the activities of ${ }^{137} \mathrm{Cs},{ }^{131} \mathrm{I},{ }^{65} \mathrm{Zn}$, ${ }^{60} \mathrm{Co},{ }^{58} \mathrm{Co},{ }^{54} \mathrm{Mn}$ and ${ }^{40} \mathrm{~K}$ were determined by gamma-ray spectrometry with acquisition times between 100,000 and 150,000 seconds (22 and 33 hours). The measurements were performed using an HPGe (EG\&G Ortec) detector of $36 \%$ efficiency, and energy resolution of $1.8 \mathrm{keV}$ (FWHM) at $1.33 \mathrm{MeV}$.

\section{Results and discussion}

\subsection{Variation in radionuclide activity concentration with distance from the Barsebäck NPP}

The activity concentrations of ${ }^{137} \mathrm{Cs},{ }^{60} \mathrm{Co},{ }^{58} \mathrm{Co},{ }^{54} \mathrm{Mn}$ and ${ }^{40} \mathrm{~K}$ in the Fucus samples in relation to the distance from the outlet of Barsebäck are given in Figure 2 and Table I. Some results concerning ${ }^{65} \mathrm{Zn}$, where the concentration was lower, are given in Table II. Moreover, ${ }^{131}$ I was found in March 2002.

The results (Fig. 2) show that the activity concentrations of ${ }^{60} \mathrm{Co},{ }^{58} \mathrm{Co}$, and ${ }^{54} \mathrm{Mn}$ decrease with distance from the point of release and that the distance dependence can be described by a power function, $C(x)=\alpha x^{-\beta}$ as in 1977 (Mattsson et al., 1980a, 1980b). From the curve fits of Figure 2 it can be deduced that the concentration in the Fucus sampled to the south of Barsebäck is about 1/4 of the concentration at the corresponding distance north of the plant. This distribution agrees roughly with the distribution of the surface water current direction in the Öresund; $30 \%$ southward, $60 \%$ nortward and $10 \%$ quiescent (SMHI, 1981). The content of ${ }^{137}$ Cs found in the Fucus samples are most likely originating from Chernobyl fallout over the Baltic Sea and its run off areas. 
THE 2002/2003 RADIONUCLIDE CONCENTRATION IN THE MARINE ENVIRONMENT

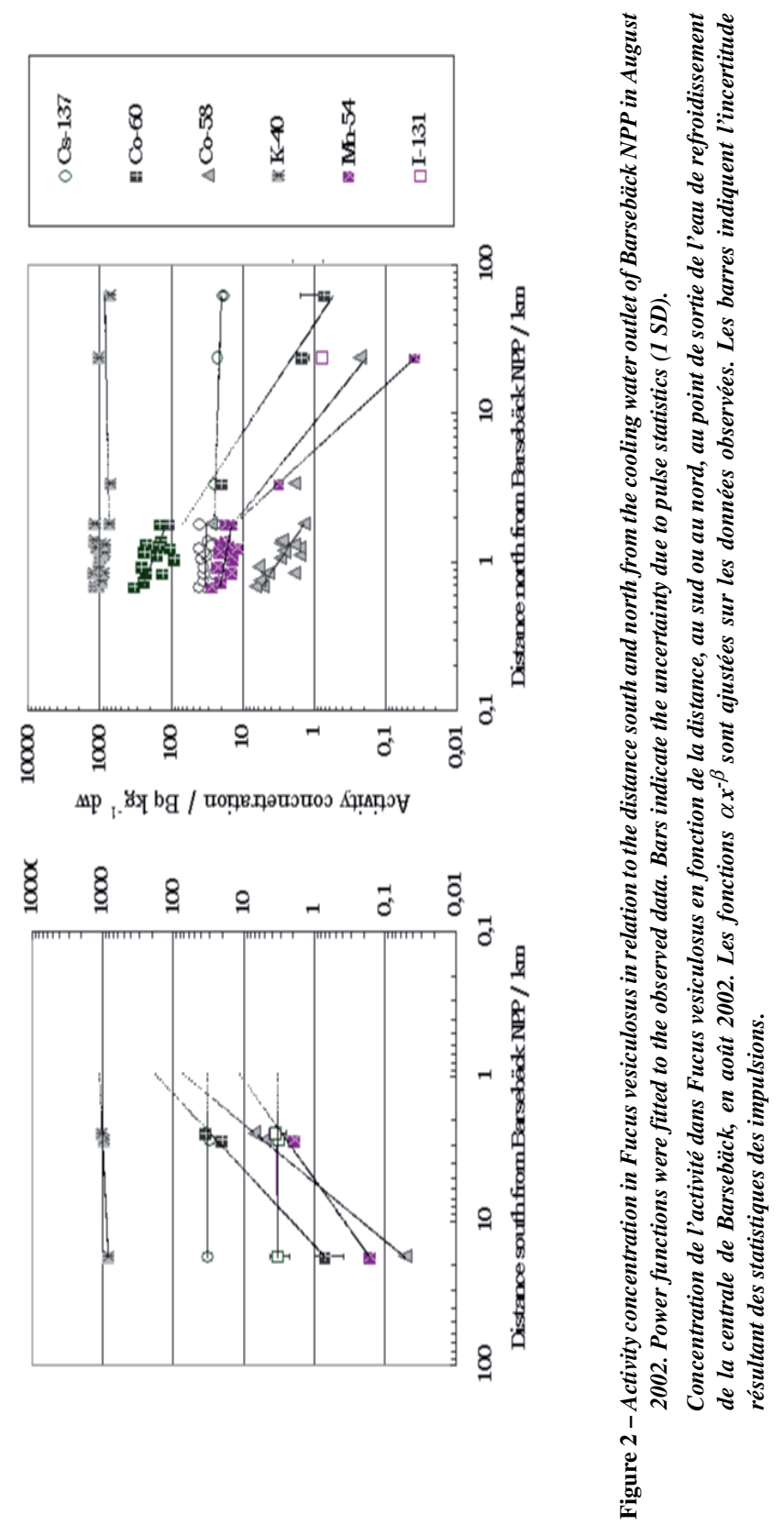

RADIOPROTECTION - VOL. $43-\mathrm{N}^{\circ} 3(2008)$ 
TABLE I

Comparison of the power exponent and their Pearson's determination coefficient (Pearson's $\boldsymbol{R}^{\mathbf{2}}$ ) at short $(<2 \mathrm{~km})$ and intermediate $(>2-50 \mathrm{~km})$ distances north and south of the Barsebäck NPP. Comparaison de l'exposant de puissance $(-\beta)$ et de leur coefficient de Pearson déterminé $\left(R^{2}\right.$ de Pearson) à faibles $(<2 \mathrm{~km})$ et moyennes $(>2-50 \mathrm{~km})$ distances au nord et au sud de Barsebäck.

\begin{tabular}{ccccccc}
\hline Radionuclide & Short range & $R^{2}$ & Intermediate & $R^{2}$ & Power exponent & Intermediate \\
North & North & range North & North & $R^{2}$ \\
range South & South \\
\hline${ }^{137} \mathrm{Cs}$ & -0.05 & 0.01 & -0.06 & 0.74 & -0.01 & 0.01 \\
${ }^{60} \mathrm{Co}$ & -0.79 & 0.33 & -1.37 & 0.97 & -1.9 & 0.99 \\
${ }^{58} \mathrm{Co}$ & -1.41 & 0.57 & -1.66 & 0.87 & -2.5 & 0.99 \\
${ }^{54} \mathrm{Mn}$ & -0.38 & 0.20 & -2.26 & 0.99 & -1.46 & 0.98 \\
${ }^{40} \mathrm{~K}$ & -0.05 & 0.01 & -0.03 & 0.12 & 0.1 & 0.90 \\
\hline
\end{tabular}

Table II

Variation of activity concentration levels of radionuclides at Skansen sampling station (1100 m north of Barsebäck NPP cooling water discharge pipe) in June 1977, March, May, August, September, October 2002 as well as January 2003.

Variation des niveaux de concentration de l'activité de radionucléides à la station de prélèvements de Skansen (1100 $\mathrm{m}$ au nord de la canalisation de rejet de l'eau de refroidissement de la centrale de Barsebäck, en juin 1977, mars, mai, août, septembre, octobre 2002 ainsi qu'en janvier 2003.

\begin{tabular}{ccccccccc}
\hline Radionuclide & $\begin{array}{c}\text { Physical } \\
\text { half-life } \\
(y)\end{array}$ & $\begin{array}{c}\text { June 12, } \\
1977 \\
(\mathrm{~Bq} / \mathrm{kg} \mathrm{dw})\end{array}$ & $\begin{array}{c}\text { March 25, } \\
2002 \\
(\mathrm{~Bq} / \mathrm{kg} \mathrm{dw})\end{array}$ & $\begin{array}{c}\text { May 13, } \\
2002 \\
(\mathrm{~Bq} / \mathrm{kg} \\
\mathrm{dw})\end{array}$ & $\begin{array}{c}\text { August 2, } \\
2002 \\
(\mathrm{~Bq} / \mathrm{kg} \mathrm{dw})\end{array}$ & $\begin{array}{c}\text { September 3, October 30, } \\
2002 \\
(\mathrm{~Bq} / \mathrm{kg} \mathrm{dw})\end{array}$ & $\begin{array}{c}\text { January 2002 } \\
(\mathrm{Bq} / \mathrm{kg} \mathrm{dw})\end{array}$ & $\begin{array}{c}2003 \\
(\mathrm{~Bq} / \mathrm{kg} \mathrm{dw})\end{array}$ \\
\hline${ }^{65} \mathrm{Zn}$ & 0.668 & 150 & 2 & 1.8 & 0 & 10 & 17 & 5 \\
${ }^{60} \mathrm{Co}$ & 5.27 & 1000 & 319 & 154 & 121 & 389 & 686 & 273 \\
${ }^{58} \mathrm{Co}$ & 0.194 & 500 & 5 & 2 & 28 & 93 & 130 & 18 \\
${ }^{54} \mathrm{Mn}$ & 0.854 & 100 & 26 & 15 & 14 & 60 & 90 & 14 \\
${ }^{40} \mathrm{~K}$ & $1.28 \times 10^{9}$ & N/A & 1164 & 1161 & 725 & 746 & 1182 & 911 \\
\hline
\end{tabular}

In the samples from March 2002, significant concentrations of ${ }^{131}$ I were also found, mainly at the points south to the Barsebäck NPP. However, there were no reports on releases of ${ }^{131} \mathrm{I}$ through the cooling water discharge of the Barsebäck NPP to the Öresund marine environment during that period (Goldstrand, 2002). The most likely source of ${ }^{131} \mathrm{I}$ originates from excreta from patients treated with ${ }^{131} \mathrm{I}$, which is released via local wastewater plants into the Öresund. 
A relationship between the concentration of radionuclides and the distance from the discharge pipe of the Barsebäck NPP is found for neutron activation products such as ${ }^{60} \mathrm{Co},{ }^{58} \mathrm{Co},{ }^{54} \mathrm{Mn}$. This distance dependence appears to be similar for the three radionuclides, with the slope of the log-log plots ranging from -1.37 to -2.26 (Tab. I). However, there is no similar distance dependence for the activity concentration of ${ }^{137} \mathrm{Cs}$. This indicates that the majority of the ${ }^{137} \mathrm{Cs}$ contents found in the Fucus samples outside the Barsebäck NPP are residual products of the releases from other sources such as the Chernobyl accidents and from Western European reprocessing plants (Mattsson and Erlandsson, 1991).

The different slopes for the nearest bay and the more distant water at intermediate ranges are explained by the different dispersion patterns of the source term. The bay north of the Barsebäck NPP, lies outside the release water plume, and the radionuclide inventory in the bay is mainly governed by currents intersecting the plume and translocation fractions of the plume towards the shore of the bay (Larsson, 2002). At intermediate distances, the dispersion of the radionuclides more closely resembles a true two-dimensional dispersion.

\subsection{Variation over the year in the radionuclide concentration levels in Fucus samples}

For ${ }^{60} \mathrm{Co}$ and ${ }^{58} \mathrm{Co}$, a marked difference in the concentration levels between seasons in 2002 is observed (Tab. II) with the highest concentration levels in autumn. The controlled releases of ${ }^{60} \mathrm{Co},{ }^{58} \mathrm{Co}$, and ${ }^{54} \mathrm{Mn}$ from the Barsebäck NPP exhibit a typical maximum value during maintenance periods of the NPP, which are performed twice a year, in the late summer as well as in early autumn in September. There is also a variation in the ${ }^{137} \mathrm{Cs}$ concentration over the year (Figs. 3 and 4).

Other factors, such as the salinity of the waters, the physicochemical concentration of the element and the seasonal biological changes in the organisms, also play an important role in the uptake of certain radionuclides by Fucus (Carlson and Erlandsson, 1991). The salinity in the sampling areas fluctuates, both in time and space, from about the average of $13 \%$ at Skansen up to 25\%o at Särdal in the near shore water. Differences in the uptake of radionuclides in Fucus vesiculosus from localities with different salinity are more pronounced for ${ }^{137} \mathrm{Cs}$, with increasing activity concentrations with decreasing salinity.

\subsection{Comparison with previous results}

The average activity concentrations of neutron activation products in the Fucus samples in the Swedish shores of Öresund are compared with the results that were 
M. ZAKARIA et al.

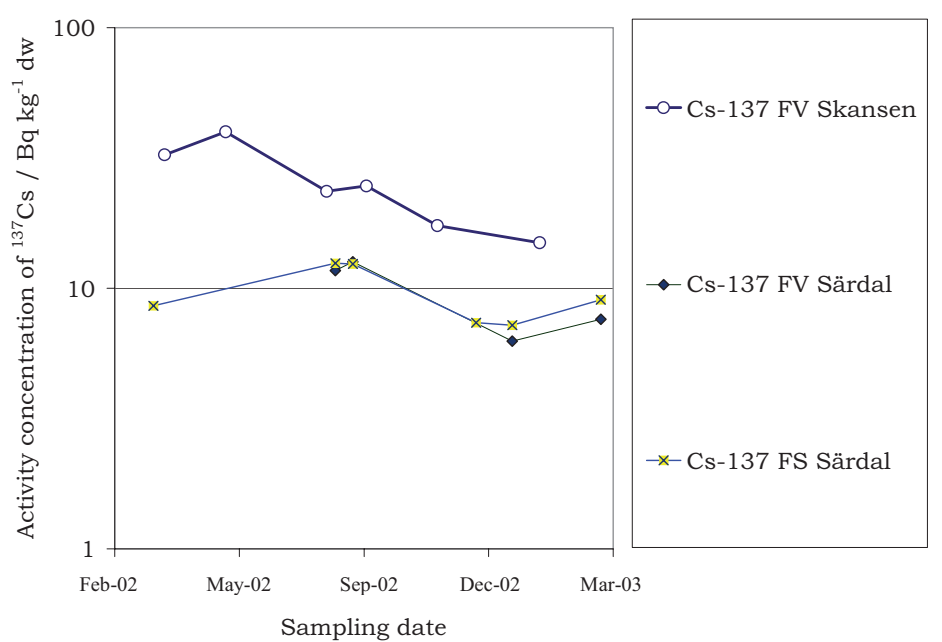

Figure 3-Activity concentration of ${ }^{137} \mathrm{Cs}$ in Fucus over the year 2002 and January and March 2003 at Skansen (1.1 km north of the Barsebäck NPP) and at Särdal (130 km north of the Barsebäck NPP). FV = Fucus vesiculosus; FS = Fucus serratus.

Concentration de l'activité de ${ }^{137}$ Cs dans Fucus durant l'année 2002, janvier et mars 2003, à Skansen (1,1 km au nord de la centrale de Barkebäck), et à Särdal (130 km au nord de Barkebäck). FV = Fucus vesiculosus ; FS = Fucus serratus.

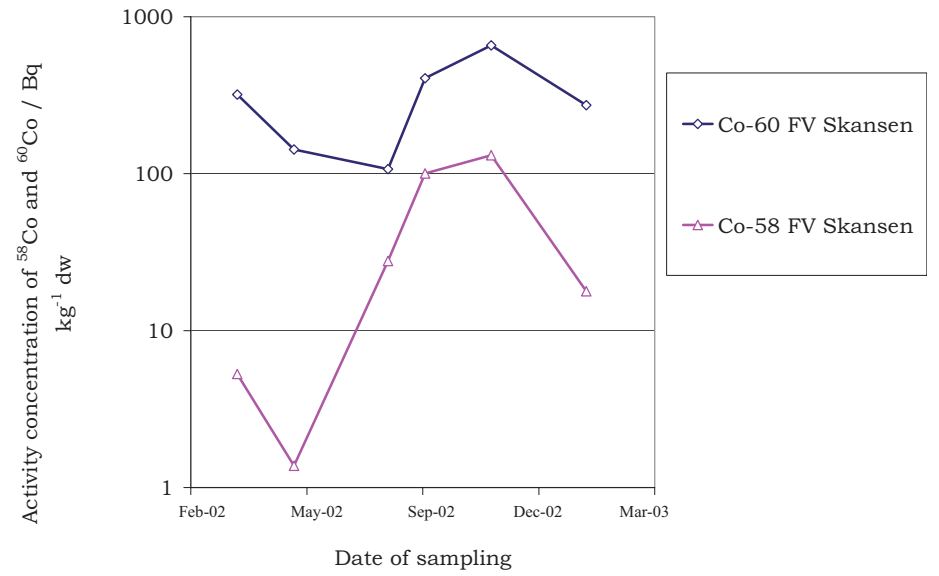

Figure 4 - Activity concentration of ${ }^{60}$ Co and ${ }^{58}$ Co in Fucus vesiculosus over the year 2002 and January 2003 at Skansen.

Concentration de l'activité de ${ }^{60} \mathrm{Co}$ et ${ }^{58}$ Co dans Fucus vesiculosus durant l'année 2002 et janvier 2003 à Skansen. 
Table III

Activity concentration of radionuclides in various species sampled at Lundåkrabukten (around $6 \mathrm{~km}$ north of the Barsebäck NPP) in August 2nd, 2002.

Concentration de l'activité de radionucléides dans diverses espèces prélevées à Lundåkrabukten (à 6 km environ au nord de la centrale de Barsebäck), le 2 août 2002.

\begin{tabular}{cccccc}
\hline Radionuclide & $\begin{array}{c}\text { Fucus vesiculosus } \\
(\mathrm{Bq} / \mathrm{kg} \mathrm{dw})\end{array}$ & $\begin{array}{c}\text { Entermorpha } \\
\text { intestinalis } \\
(\mathrm{Bq} / \mathrm{kg} \mathrm{dw})\end{array}$ & $\begin{array}{c}\text { Zostera marina } \\
(\mathrm{Bq} / \mathrm{kg} \mathrm{dw})\end{array}$ & $\begin{array}{c}\text { Mytilus edulis with } \\
\text { microalgae on their } \\
\text { surface } \\
(\mathrm{Bq} / \mathrm{kg} \mathrm{dw})\end{array}$ & $\begin{array}{c}\text { Mytilus edulis clean } \\
\text { from microalgae on } \\
\text { their surface } \\
(\mathrm{Bq} / \mathrm{kg} \mathrm{dw})\end{array}$ \\
\hline${ }^{13} 7 \mathrm{Cs}$ & 24 & 15 & 24 & 4 & 4 \\
${ }^{60} \mathrm{Co}$ & 3 & 2 & 11 & 0.3 & $<\mathrm{MDA}$ \\
${ }^{54} \mathrm{Mn}$ & $<\mathrm{MDA}$ & 1 & 2 & 2 & 1 \\
${ }^{40} \mathrm{~K}$ & 745 & 804 & 1137 & 92 & 70 \\
\hline
\end{tabular}

obtained in 1977 (Tab. II). It is evident that all activity concentration levels in 2002 were significantly lower than those in 1977 , especially for ${ }^{65} \mathrm{Zn}$. Though it can not be the only explanation for such a decrease in all activity concentration, one could expect some decrease as in 2002/2003 only one of the two units had been operating.

\subsection{Concentrations of radionuclides in various marine species}

Of all the species sampled at Lundåkrabukten, eelgrass, Zostera marina, exhibited the highest concentration of ${ }^{60} \mathrm{Co}$ and ${ }^{54} \mathrm{Mn}$. Eelgrass has also the possibility to accumulate ${ }^{137} \mathrm{Cs}$ at similar concentration as Fucus vesiculosus (Tab. III). Within the marine ecology eelgrass is considered as a useful bioindicator of the general ecological status of the shallow waters and estuaries (e.g.; PTMSC, 2003). The results found here indicate that eelgrass may also have potential as a sensitive bioindicator of radiation level in marine environments.

\section{Conclusions}

The activity concentration of gamma emitting radionuclides in Fucus from the bay just north of Barsebäck was in 2002/2003 dominated by (in order of decreasing concentration): natural ${ }^{40} \mathrm{~K},{ }^{60} \mathrm{Co}$ from the plant, ${ }^{137} \mathrm{Cs}$ mainly from the Chernobyl releases in 1986 and from western reprocessing plants, ${ }^{54} \mathrm{Mn}$ and ${ }^{58} \mathrm{Co}$ from the plant. The concentration of Barsebäck-produced radionuclides is lower per generated $\mathrm{MW}_{\mathrm{e}}$ than in 1977.

At intermediate ranges, the activity concentration of various gamma-emitting radionuclides in Fucus decreases as the distance increases from the Barsebäck NPP in a fashion that is predicted by the theory of two-dimensional dispersion. 
The concentration levels of various radionuclides are higher in Fucus during the late spring and summer times, while they reach their minimum by the end of winter season. Zostera marina appears to be a good bio-indicator for indicating the releases of neutron activation products of radionuclides from nuclear power plants to the marine waters, especially for ${ }^{60} \mathrm{Co}$ and ${ }^{54} \mathrm{Mn}$.

It is not likely that any effects from the very marginal absorbed dose contribution from the Barsebäck NPP releases can be found even in the nearest environment.

\section{REFERENCES}

Carlson L., Erlandsson B. (1991) Effects of Salinity on the Uptake of Radionuclides by Fucus vesiculosus, J. Environm. Radioact. 13, 309-322.

Goldstrand C. (2002) Barsebäcksverkets utläppskontroll 1:a halvåret 2002: Redovisning av radioaktiva utsläpp till luft och vatten under 1:a hlvåret 2002. SSI-document BVT-B2-200209-105, Swedish Radiation Protection Authority (SSI), 2002.

Holm E. (1994) Sources and distribution of anthropogenic radionuclides in the marine environment, Holm E., Ed., Radioecology lectures in environmental radioactivity. World Scientific, Singapore, pp.76-77.

Larsson P. (2002) Personal communication, Department of Chemical Ecology/Ecotoxicology, Lund University, Lund, Sweden.

Mattsson S., Erlandsson B. (1991) Variation of the ${ }^{137}$ Cs levels in Fucus from the Swedish westcoast during a 25 years period, Moberg L., Ed., The Chernobyl fallout in Sweden- Results from a research programme on environmental radiology, Swedish Radiation Protection Authority (SSI), Stockholm, pp. 143-144.

Mattsson S., Finck R., Nilsson M. (1980a) Distribution of activation products from Barsebäck nuclear power plant (Sweden) in the marine environment. Temporal and spatial variations as established by seaweed, Environmental Pollution (Ser. B) 1, 105-115.

Mattsson S., Nilsson M., Holm E. (1980b) Radioecological studies of activation products released from a nuclear power plant into the marine environment, Proceedings of the 5th International Congress of IRPA, Jerusalem, Vol. III, pp. 323-326.

Nilsson M., Dahlgaard H., Edgren M., Holm E., Mattsson S., Notter M. (1980) Radionuclides in Fucus from inter-Scandinavian water. Proceedings of the International Symposium on the Impacts of Radionuclide Releases into the Marine Environment, International Atomic Energy Agency, Vienne, IAEA-SM-248, pp. 107-111.

PTMSC (2003) Website accessed in 2003: http://www.ptmsc.org/html/eelgrass.html. Port Townsend Marine Science Center, 2003, Fort Worden State Park, Port Townsend, WA, USA.

SMHI (1981) Swedish Meterological and Hydrological Institute, Oceanographic investigations outside the nuclear power plant of Barsebäck 1967-1980, Report 1981-05-08, Dnr 79/324, Norrköping, Sweden.

Wijk H., Luning M. (2001) Utsläpps- och omgivningskontroll vid de kärntekniska anläggningarna 2000. Swedish Radiation Protection Authority (SSI), Report 2001:25. 